RESEARCH ARTICLE

\title{
Response of Blackgram Cultivars to Elevated Tropospheric Ozone
}

Periyasamy Dhevagi ${ }^{1 *}$, Ambikapathi Ramya ${ }^{1}$, Ramesh Poornima ${ }^{1}$ and Sengottiyan Priyatharshini ${ }^{2}$

$1^{*}$ Department of Environmental Sciences, Tamil Nadu Agricultural University, Coimbatore, 641003, Tamil Nadu, India

${ }^{2}$ Department of Crop Management, Vanavarayar Institute of Agriculture, Pollachi-642103, Tamil Nadu, India

\begin{abstract}
As a secondary pollutant, Tropospheric ozone is inadvertently increasing every year, thereby causing severe loss to agricultural crops. The present study aimed at evaluating the response of tropospheric ozone against blackgram varieties. Eight ruling blackgram varieties (V.B.N. 1, V.B.N. 2, V.B.N. 3, V.B.N. 5, V.B.N. 6, V.B.N. 7, V.B.N. 8 and CO 6) were exposed to elevated tropospheric ozone concentration (50 ppb) in an open-top chamber. The exposure was given during 31 days after sowing (D.A.S.) to 40 D.A.S. for seven hours (10.00 h-17.00 h). The changes in physiological, biochemical, growth, and yield traits were observed by comparing them with control (ambient condition). Results indicate that physiological, biochemical, growth, and yield traits significantly differed under ozone stress. Amongst all varieties, the reduction of all observed traits was higher in V.B.N. 3 and least in V.B.N. 8. The reduction of photosynthetic rate, stomatal conductance, and chlorophyll content was higher in V.B.N. 3 (33.57, 29.17 and 35.67 \%) and least in V.B.N. $8(26.23,22.92$ and $31.78 \%)$. In the case of biochemical traits, in V.B.N. 3 , the malondialdehyde and proline content increased twice and ascorbic acid declined by $39.85 \%$. However, in V.B.N. 8, malondialdehyde and proline content increased by 78.26 and $89.01 \%$; while ascorbic acid decreased by $36.31 \%$ only. Similarly, 100-grain weight reduced in V.B.N. 3 by $8.69 \%$ while it was only $5.37 \%$ in V.B.N. 8. The current investigation revealed that V.B.N. 3 is highly sensitive, while V.B.N. 8 is tolerant to ozone stress.
\end{abstract}

Keywords: Tropospheric ozone; Blackgram; Physiological; Biochemical; Growth; Yield attributes

\section{INTRODUCTION}

Tropospheric ozone $\left(\mathrm{O}_{3}\right)$ has become one of the world's most widely dispersed toxic pollutants in the last several decades (I.P.C.C. 2007; Booker et al., 2009; Brauer et al., 2016), exerting severe impact on humans, plants, and animals (Cho et al., 2011; Ainsworth, 2017; Agathokleous et al., 2018; Osborne et al., 2019). This secondary pollutant, under bright sunshine, is produced by a series of photochemical reactions involving carbon monoxide ( $\mathrm{CO})$, methane $\left(\mathrm{CH}_{4}\right)$, nitrogen oxides (NOx), as well as volatile organic compounds (V.O.C.s) (Collins et al., 1997; Monks et al., 2015). Besides anthropogenic activities and other industrial emissions, and transportation also contributes to ozone production in metropolitan areas. Ground-level ozone is an issue in rural places as well. Although being hundreds or thousand miles away from the original source, higher concentration of tropospheric ozone is experienced in rural areas wherein a majority of land is devoted to agricultural operations (Prather et al., 2003; Agrawal et al., 2006; Williams et al., 2016). In recent decades, the background $\mathrm{O}_{3}$ concentration has risen by between 0.5 and 2 percent every year (Vingarzan, 2004). The projected trends in ozone precursors emission increases the global average tropospheric ozone concentration by 20-25\% between 2015 and 2050, further raising by $40-60 \%$ by 2100 (Meehl et al., 2007). Crop yield losses are predicted throughout the world by the year 2030, and India would be suffering the worst situation when it comes to relative yield (Van Dingenen et al., 2009). It has been estimated that current levels of $\mathrm{O}_{3}$ can result in economic losses of \$14-26 billion, with China and India alone accounting for 40\% (Van Dingenen et al., 2009; Danh et al., 2016; Ashrafuzzaman et al., 2017; Harmens et al., 2018; Mills et al., 2018).

Ozone enters the leaf through stomatal pores and generates reactive oxygen species (ROS OS) as they reach the intercellular spaces, and exerts oxidative stress by reacting with plant's leaves (Booker et al., 2009). So, the antioxidant defense system is activated, which plays a vital role in keeping ROS levels under control, thereby preserving the equilibrium of the cell's redox potential. Therefore, it is clear that $\mathrm{O}_{3}$ stress results in decreased carbon $107 \mid 10-12$ | 1 
assimilation and altered carbon partitioning in plants (McCrady and Andersen, 2000), reduced yield, and altered crop quality (Singh et al., 2009; Tripathi and Agrawal, 2012; Sarkar et al., 2015). Several studies have been reported that tropospheric ozone significantly reduced the crop yield (Feng and Kobayashi, 2009; Sawada and Kohno, 2009; Rai et al., 2010; Sarkar and Agrawal, 2010; Mishra et al., 2013; Singh et al., 2014; Ziemke et al., 2019). Tropospheric ozone exhibited significant toxicity on various crops like snap bean (Flowers et al., 2007), mung bean (Chaudhary and Agrawal, 2015), potato (Suganthy and Udayasoorian, 2016), garlic (Gayathri et al., 2019), cauliflower (Sethupathi et al., 2018), forests (Elvira et al., 2004; Murugaragavan and Udayasoorian, 2016) and rice (Ramya et al., 2021 $\mathrm{a}, \mathrm{b})$.

India, being one of the fastest expanding countries in terms of economy in the Asian region, endures a significant increase in tropospheric ozone concentration (Berntsen et al., 1996; Brasseur et al., 1998; Oksanen et al., 2013). Agriculture in India is the country's most populous economic sector, and it ranks second in the world (Ghude et al., 2014; Brauer et al., 2016). Increasing levels of $\mathrm{O}_{3}$ pollution are a serious concern for India's agriculture, which is home to a fifth of the world's hungry people. As time goes on, reports indicate that the ambient levels of $\mathrm{O}_{3}$ are growing in the northern region of India (Pandey et al., 1992; Agrawal et al., 2002; Tiwari et al., 2008; Sarkar and Agrawal 2010), which might significantly result in crop yield loss (Agrawal et al., 2005; Singh and Agrawal, 2010; Agathokleous et al., 2015; Sugai et al., 2018). In Tamil Nadu, various regions like Chennai (Pulikesi et al., 2006; Padma et al., 2014; Muthulakshmi et al., 2017; Prabakaran et al., 2017; Mohan and Saranya, 2019), Ooty (Udayasoorian et al., 2013), Suchindrum (Sharma et al., 2012), Kanyakumari (Sharma and Nagaveena, 2016), Tirunelveli (Usha et al., 2018) were reported to experience higher concentration of ground-level ozone.

Pulses, one of the vital agricultural crops, occupies 252.29 lakh hectares of agricultural land with a production of 16.47 million tonnes (D.A.C. \& F.W., 2018). They are susceptible to tropospheric ozone, and a critical level of $40 \mathrm{ppb}$ is required for $5 \%$ yield reduction (Mills et al., 2018). Blackgram is one of the vital pulse crop containing $26 \%$ protein and plays a major role in the Indian diet. Studies using Open-top chambers (OTC) have been extensively studied over the last 50 years to determine the yield losses owing to different air pollutants, including $\mathrm{O}_{3}$. This study investigates the response of $\mathrm{O}_{3}$ against eight ruling blackgram varieties since it is one of the vital pulses in India and provides a major protein requirement in the human's diet.

\section{MATERIAL AND METHODS}

\section{Study Location and plant materials}

The study was conducted at wetland $\left(11.00^{\circ}\right.$ $\mathrm{N}, 76.92^{\circ} \mathrm{E}$ at an elevation of $426.72 \mathrm{~m} \mathrm{amsl}$ ) of Tamil Nadu Agricultural University, During the experimental period, the maximum temperature ranged from 29.9 to $30.8{ }^{\circ} \mathrm{C}$; while the minimum temperature varied between 17.5 and $18.2^{\circ} \mathrm{C}$. The maximum relative humidity was from 71 to $85 \%$ and the minimum relative humidity varied from 48 to $54 \%$. The study area is located in the under semi - arid tropics. The soil was deep clay loam with taxonomical classification as Typic Haplustalf. The $\mathrm{pH}$ was found to be 8.05 with an E.C. of $0.39 \mathrm{dS} \mathrm{m}^{-1}$. The available nitrogen was found to be low $(217 \mathrm{~kg}$ $\mathrm{ha}^{-1}$ ) with medium available phosphorus $(11.8 \mathrm{~kg}$ $\mathrm{ha}^{-1}$ ) and high available potassium (295 kg ha-1). The soil had low organic carbon content (0.48\%).

The study was performed on eight ruling blackgram varieties (V.B.N. 1, V.B.N. 2, V.B.N. 3, V.B.N. 5, V.B.N. 6, V.B.N. 7, V.B.N. 8, and C06) which was obtained from National Pulses Research Centre situated at Vamban. Soil test crop response (S.T.C.R.) based fertilizer application was given with regular irrigation to maintain uniform soil moisture.

\section{Experimental design}

A pot experiment was conducted in two OpenTop Chamber (OTC) of standard size $(3.5 \times 3.5$ $\mathrm{m})$, which were installed in the experimental site and consisted of two treatments - Control - nonfiltered chamber (N.F.C.) and N.F.C. + elevated $\mathrm{O}_{3}$ (50 ppb). The elevated ozone was given using an ozone generator (A4G, Faraday, India). An ozone feed rate of $0.6 \mathrm{mg} / \mathrm{min}$ was maintained throughout the experimental period (Van Leeuwen, 2015) and the inlet oxygen flow was maintained at $12 \mathrm{~L} \mathrm{~min}^{-1}$ to regulate the ozone flow. The plants were exposed to an elevated ozone concentration of $50 \mathrm{ppb}$ in the open-top chamber during the flowering stage from 31 D.A.S. (days after sowing) to 40 D.A.S. for 7 hours $(10.00 \mathrm{~h}-17.00 \mathrm{~h})$ with an AOT40 value of $0.714 \mathrm{ppm}$. h. The emission was given $30 \mathrm{~cm}$ above the canopy of the plant. In the control chamber, the ozone concentration was less than $7 \mathrm{ppb}$.

\section{Plant sampling}

Random plants were sampled in nine replications from each OTC for each blackgram variety $(n=8$ variety $x 9$ replications) and analyzed. Sampling was done after 10 days of ozone exposure and was used to analyze all physiological and biochemical traits. Sampling was done during the harvest or crop maturity stage for growth and yield traits.

\section{Plant analysis}

Leaf injury percentage (L.I.P.) ranging from 0 
to 100 was given to all the blackgram varieties (Chaudhary et al., 2013). Physiological parameters like photosynthetic rate (A), stomatal conductance (gs), and chlorophyll content were measured at different points of the leaf during day light (09.30 AM to 12.00 PM) before and after 10 days of ozone exposure. The youngest leaf was chosen to measure the physiological traits. A portable photosynthetic system (A.D.C. Bio Scientific LCpro-SD System, U.K.) was used to measure $A$ and gs; while chlorophyll content meter (CCM-200+, U.S.A.) was used to measure the chlorophyll content. Biochemical traits like malondialdehyde (MDA), proline, and ascorbic acid (AsA) were also analyzed. The standard protocol given by Heath and Packer (1968) was used to measure; while proline was measured using the procedure given by Bates et al. (1973) and for ascorbic acid (AsA) content the method given by Keller and Schwager (1977) was followed.

During the harvest stage, growth traits like root length (R.L.), shoot length (S.L.), and plant weight (P.W.), yield traits like number of branches per plant (N.B.P.), number of nodules per plant (N.N.P.), number of leaves per plant (N.L.P.), number of pods per plant (NPP), number of seeds per plant (N.S.P.), pod length (P.L.) and 100-grain weight (100 GW) were measured.

\section{Statistical analysis}

The significant difference amongst the cultivars and treatment were statistically evaluated using one-way ANOVA test, while their interactions were done by two-way ANOVA test. S.P.S.S. (Ver. 16.0.0), a statistical tool was used to perform the tests. The variation among the treatment means was studied using Tukey method and Pearson's correlation coefficient was used to determine the degree of correlation.

\section{RESULTS AND DISCUSSION}

\section{Leaf injury percentage}

Exposure to elevated ozone exhibited various leaf injury symptoms, and the leaf injury percentage (L.I.P.) varied among the cultivars. The symptoms were observed to intensify with an increasing exposure period. Younger leaves with early necrotic symptoms were identified in V.B.N. 1, V.B.N. 2, V.B.N. 3, and CO6, indicating its sensitivity towards ozone stress. The L.I.P. for the above-mentioned varieties was found to be $40.00,40.00,50.67$ and $40.33 \%$, respectively. Similarly, varieties like V.B.N. 5 (27.00\%), V.B.N. 6 (34.00\%), V.B.N. 7 (36.67\%), and V.B.N. 8 (23.67\%) exhibited lesser injury, validating their tolerance to ozone stress. Amongst all cultivars, the highest L.I.P. was observed in V.B.N. 3 (50.67\%), while the least was observed in V.B.N. 8 (23.67\%). Furthermore, cultivar-specific variation reported in this study demonstrated that our test blackgram cultivars have varying resistance levels to high ozone exposure. This tendency might be explained by a more significant rise in reactive oxygen species (ROS) in comparison to an increase in ozone levels. According to Weadow et al. (2021), superoxide is produced under ozone exposure, causing leaf damage. Chaudhary et al. (2013), revealed that extended ozone exposure intensified the leaf injury in mung bean cultivars and that foliar L.I.P. can demonstrate different levels of ozone sensitivity of test cultivars. Similarly, Mishra and Agrawal (2015) found that ROS buildup inside the plant system caused foliar and cellular damage.

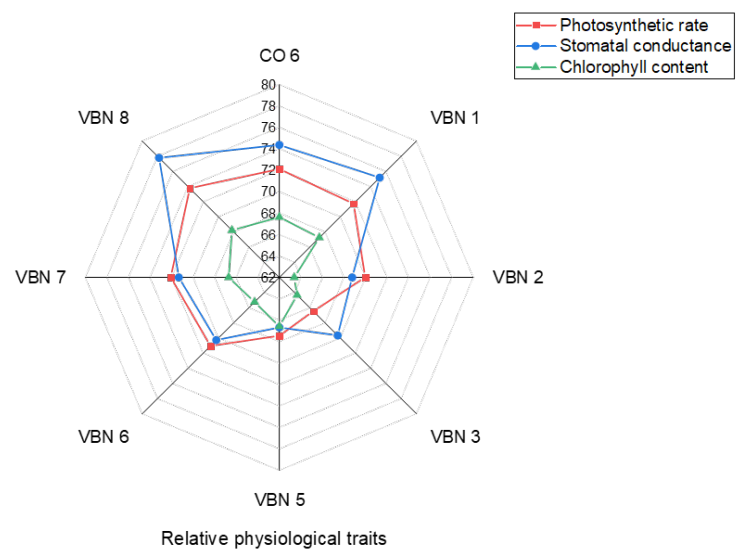

Figure 1. Relative physiological traits of blackgram varieties under 50 ppb ozone stress

\section{Physiological traits}

Elevated ozone exposure significantly reduced the physiological traits like photosynthetic rate, stomatal conductance, and chlorophyll content in all blackgram varieties. The photosynthetic rate varied from 13.04 to $15.02 \mu \mathrm{mol} \mathrm{CO}_{2} \mathrm{~m}^{-2} \mathrm{~s}^{-1}$. Similarly, stomatal conductance varied between 0.33 to 0.39 mol $\mathrm{H}_{2} \mathrm{O} \mathrm{m}^{-2} \mathrm{~s}^{-1}$ and chlorophyll content between 18.34 and 20.67 (Table 1). V.B.N. 3 recorded the highest reduction in all physiological traits among the varieties, while V.B.N. 8 recorded the least reduction. This indicates that V.B.N. 3 is highly sensitive to ozone stress while V.B.N. 8 is tolerant. Like L.I.P., the varietal difference was also observed in physiological traits. Generally, the opening and closing of stomata regulate the entry of tropospheric ozone into the apoplast of the plant system (Tingey and Hogsett, 1985; Daszkowska-Golec and Szarejko, 2013; Rai, 2020). In this study, the reduction in photosynthetic rate and stomatal conductance is associated with the offset mechanism to prevent pollutant entry through stomatal closure (Fiscus et al., 2005; Betzelberger et al., 2010; Ghosh et al., 2020).

Moreover, variation in the partial pressure of the guard cells and loss of osmotic potential might also lead to the closure of stomata under ozone $107 \mid 10-12$ | 3 
stress. With stomatal closure, the ability to uptake $\mathrm{CO}_{2}$ declines, thereby decreasing the photosynthetic rate. Similar results were reported in mung bean (Mishra and Agrawal, 2015) and soybean (Sun et al., 2014; Rai et al., 2015; Ramya et al., 2021 a,b). The decline in chlorophyll content due to ozone stress might be attributed to the destruction of the chloroplast structure, thereby suppressing chlorophyll synthesis (Castagna et al., 2001; Biswas and Jiang, 2011; Jing et al., 2016). Moreover, the decline in the carotenoid pigments might also reduce the chlorophyll content (Salvatori et al., 2013). The results corroborate with studies given by Tetteh et al. (2016). The relative physiological characteristics of blackgram varieties varied among each other with a mean value of $70.80,71.39$, and $66.63 \%$ for stomatal conductance, photosynthetic rate, and chlorophyll content (Fig.1). The greater deviation was observed in stomatal conductance indicating

\section{Biochemical traits}

In all blackgram varieties, malondialdehyde content (MDA) significantly increased under ozone stress compared to control and a varietal variation was also observed. The MDA content ranged from 1.07 to $1.49 \mu \mathrm{mol} \mathrm{g}{ }^{-1}$ F.W. in control and from 2.27 to $2.97 \mu \mathrm{mol} \mathrm{g}^{-1}$ F.W. under $50 \mathrm{ppb}$ ozone stress. The entry of tropospheric ozone into the plant system induces the generation of reactive oxygen species (ROS), thereby damaging the membrane components like lipids, chloroplast, nucleic acids, and proteins (Blokhina et al., 2003; Hasanuzzaman et al., 2012; Saxena et al., 2019). The induction in that stomatal conductance is highly responsive to ozone stress compared to the photosynthetic rate and chlorophyll content.

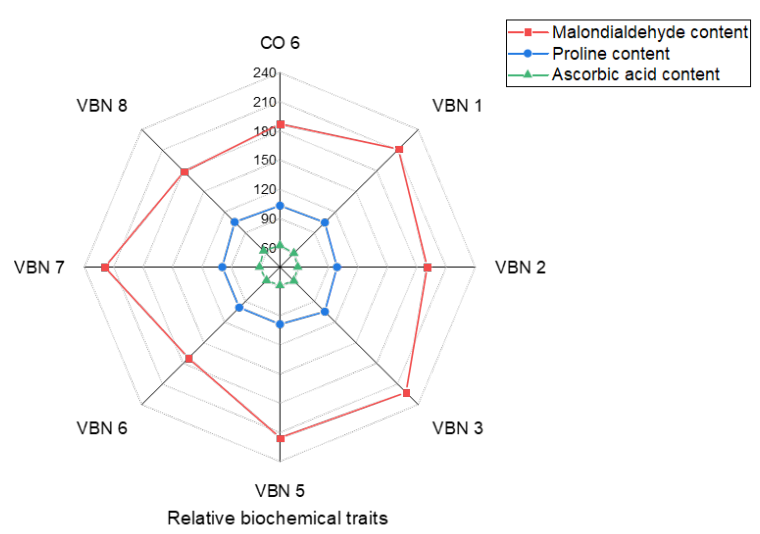

Figure 2. Relative biochemical traits of blackgram varieties under 50 ppb ozone stress

MDA content under ozone stress is related to its sensitivity suggesting greater lipid peroxidation of the membrane compared to ambient conditions. Furthermore, the destruction of membrane components due to ROS generation inhibits the scavenging ability of the plant cell (Sanmartin et al., 2003). The results corroborate with the findings of Mishra and Agrawal (2015) observed a 30.8 and $21 \%$ increase in MDA content of mung bean cultivars under $68.9 \mathrm{ppb}$ ozone stress. Significant reduction in biochemical traits was also observed in cauliflower (Sethupathi et al., 2018). garlic (Gayathri et al., 2019) and rice (Ramya et al., 2021a).

Table 1. Physiological traits of blackgram varieties under 50 ppb ozone stress

\begin{tabular}{|c|c|c|c|c|c|c|}
\hline \multirow{2}{*}{ Variety } & \multicolumn{2}{|c|}{ Photosynthetic rate } & \multicolumn{2}{|c|}{ Stomatal conductance } & \multicolumn{2}{|c|}{ Chlorophyll content } \\
\hline & Control & 50 ppb & Control & 50 рpb & Control & 50 ppb \\
\hline co 6 & $18.48 \pm 0.37$ & $13.33 \pm 0.22$ & $0.52 \pm 0.04$ & $0.39 \pm 0.01$ & $28.57 \pm 0.70$ & $19.32 \pm 0.70$ \\
\hline V.B.N 1 & $20.52 \pm 0.28$ & $14.72 \pm 0.44$ & $0.51 \pm 0.04$ & $0.38 \pm 0.01$ & $29.37 \pm 0.60$ & $19.75 \pm 0.87$ \\
\hline V.B.N 2 & $18.79 \pm 0.67$ & $13.15 \pm 0.85$ & $0.48 \pm 0.01$ & $0.33 \pm 0.02$ & $28.93 \pm 0.85$ & $18.34 \pm 0.35$ \\
\hline V.B.N 3 & $19.63 \pm 0.55$ & $13.04 \pm 0.47$ & $0.48 \pm 0.01$ & $0.34 \pm 0.02$ & $29.83 \pm 0.90$ & $19.19 \pm 0.55$ \\
\hline V.B.N 5 & $20.16 \pm 0.35$ & $13.60 \pm 0.13$ & $0.49 \pm 0.01$ & $0.33 \pm 0.01$ & $29.00 \pm 1.00$ & $19.30 \pm 0.66$ \\
\hline V.B.N 6 & $21.15 \pm 0.33$ & $15.02 \pm 0.27$ & $0.49 \pm 0.01$ & $0.35 \pm 0.02$ & $29.83 \pm 0.96$ & $19.47 \pm 0.84$ \\
\hline V.B.N 7 & $19.02 \pm 0.35$ & $13.71 \pm 0.33$ & $0.50 \pm 0.01$ & $0.36 \pm 0.03$ & $29.23 \pm 0.33$ & $19.50 \pm 0.70$ \\
\hline V.B.N 8 & $18.53 \pm 0.68$ & $13.67 \pm 0.71$ & $0.48 \pm 0.01$ & $0.37 \pm 0.01$ & $30.30 \pm 0.50$ & $20.67 \pm 0.55$ \\
\hline \multicolumn{3}{|c|}{$\begin{array}{c}\text { ANOVA } \\
\text { (P values) }\end{array}$} & $\begin{array}{l}\text { Photosynthetic rate } \\
\left(\mu \mathrm{mol} \mathrm{CO} \mathrm{C}^{-2} \mathrm{~s}^{-1}\right)\end{array}$ & \multicolumn{2}{|c|}{$\begin{array}{c}\text { Stomatal conductance } \\
\left(\mathrm{mol} \mathrm{H}_{2} \mathrm{O} \mathrm{m}^{-2} \mathrm{~s}^{-1}\right)\end{array}$} & Chlorophyll content \\
\hline \multicolumn{3}{|l|}{ Varieties } & $<0.001$ & \multicolumn{2}{|c|}{0.064} & 0.340 \\
\hline \multicolumn{3}{|l|}{ Treatment } & $<0.001$ & \multicolumn{2}{|c|}{$<0.001$} & $<0.001$ \\
\hline \multicolumn{2}{|c|}{ Varieties $\times$ Treatment } & & 0.520 & \multicolumn{2}{|c|}{0.821} & 0.964 \\
\hline \multicolumn{7}{|c|}{ Treatment means } \\
\hline \multicolumn{2}{|l|}{ Control } & & 18.53 & \multicolumn{2}{|c|}{0.49} & 29.38 \\
\hline \multicolumn{2}{|l|}{ Ozone } & & 13.67 & \multicolumn{2}{|c|}{0.36} & 19.44 \\
\hline
\end{tabular}

$n=9$ (Sample size, $N=144$ )

$107 \mid 10-12$ | 4 


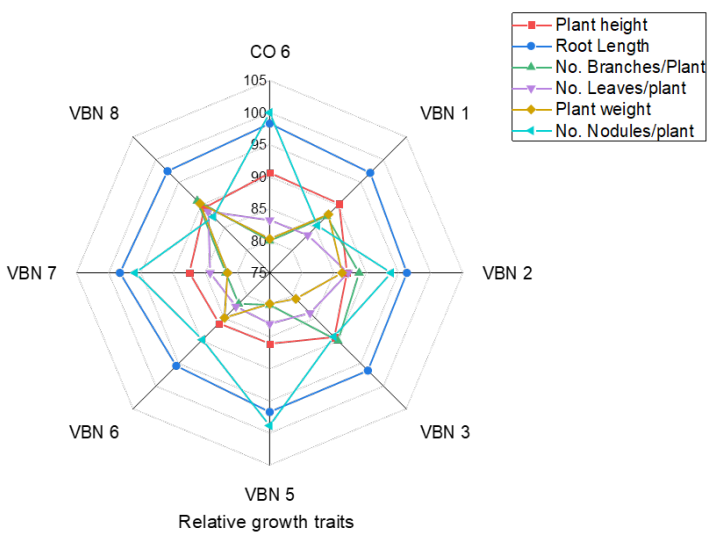

Figure 3. Relative growth traits of blackgram varieties under $\mathbf{5 0}$ ppb ozone stress

Unlike MDA content, the ascorbic acid content was found to decline in all blackgram cultivars under ozone stress compared to control. The ascorbic acid varied between 1.33 to $1.72 \mathrm{mg} \mathrm{g}^{-1} \mathrm{~F} . \mathrm{W}$. in control and between 0.78 and $1.03 \mathrm{mg} \mathrm{g}^{-1} \mathrm{~F} . \mathrm{W}$. in elevated ozone condition. This decline might be due to the non-enzymatic defense mechanism of blackgram varieties under ozone stress. Antioxidants are produced to nullify the ROS toxicity (Caregnato et al., 2013) and the redox condition of AsA becomes unstable, eventually resulting in insufficient detoxification by AsA (Tetteh et al., 2016). The proline content increased under ozone stress varying from 4.81 to $6.08 \mu \mathrm{mol} \mathrm{g}^{-1} \mathrm{~F} . \mathrm{W}$. under ambient conditions and from 10.15 to $13.46 \mu \mathrm{mol} \mathrm{g}^{-1}$ F.W. under $50 \mathrm{ppb}$ ozone stress. This increased proline content might be attributed due to the scavenging ability of proline under ozone stress (Gill and Tuteja, 2010; Rejeb et al., 2014). The relative biochemical traits showed variation with mean values of 201.01, 60.11 and 202.00\% in MDA, AsA and proline content (Fig.2).

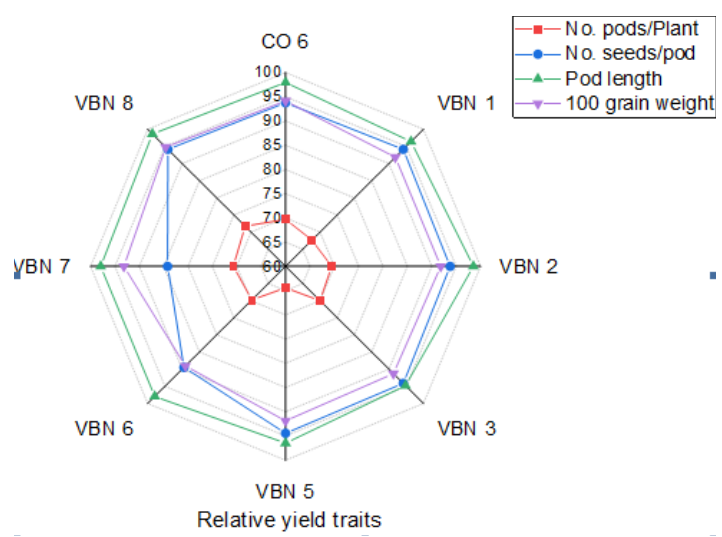

Figure 4. Relative yield traits of blackgram varieties under $50 \mathrm{ppb}$ ozone stress

\section{Growth and yield characteristics}

Elevated ozone stress significantly decreased all the growth and yield traits in all blackgram cultivars. The shoot length varied from 20.67 to $37.27 \mathrm{~cm}$ (ambient) and from 17.80 to $33.30 \mathrm{~cm} \mathrm{(50} \mathrm{ppb}$ ozone stress); while root length ranged between 13.47 and $16.20 \mathrm{~cm}$ under control and from 13.00 to $16.57 \mathrm{~cm}$ under ozone stress. In the case of number of branches per plant, under ozone stress, the highest value was observed in V.B.N. 8 (3.33) while the least was observed in V.B.N. 1 (2.33).

Table 2. Correlation between physiological, biochemical, growth and yield parameters

\begin{tabular}{|c|c|c|c|c|c|c|c|c|c|c|c|c|c|c|c|c|c|}
\hline Parameters & LIP & $100 \mathrm{GW}$ & PL & NSP & NPP & PW & NLP & NBP & NNP & $\mathbf{R L}$ & SL & AsA & Proline & MDA & Chl & Gs & A \\
\hline LIP & 1 & & & & & & & & & & & & & & & & \\
\hline $100 \mathrm{GW}$ & -0.57 & 1 & & & & & & & & & & & & & & & \\
\hline PL & -0.28 & 0.34 & 1 & & & & & & & & & & & & & & \\
\hline NSP & -0.25 & 0.11 & -0.29 & 1 & & & & & & & & & & & & & \\
\hline NPP & -0.61 & 0.31 & 0.42 & 0.35 & 1 & & & & & & & & & & & & \\
\hline PW & -0.31 & 0.12 & 0.44 & 0.59 & 0.37 & 1 & & & & & & & & & & & \\
\hline NLP & -0.52 & 0.54 & 0.51 & 0.19 & 0.50 & 0.64 & 1 & & & & & & & & & & \\
\hline NBP & -0.61 & 0.43 & 0.42 & 0.40 & 0.42 & 0.65 & 0.70 & 1 & & & & & & & & & \\
\hline NNP & 0.47 & 0.47 & 0.09 & -0.27 & -0.01 & 0.02 & -0.18 & -0.36 & 1 & & & & & & & & \\
\hline $\mathbf{R L}$ & -0.53 & 0.85 & 0.69 & 0.53 & 0.24 & 0.19 & 0.11 & 0.21 & 0.75 & 1 & & & & & & & \\
\hline PL & -0.52 & 0.57 & 0.56 & 0.36 & 0.33 & 0.69 & 0.11 & 0.33 & 0.53 & 0.57 & 1 & & & & & & \\
\hline AsA & -0.65 & 0.77 & 0.29 & 0.56 & 0.58 & 0.25 & 0.35 & 0.14 & 0.36 & 0.67 & 0.65 & 1 & & & & & \\
\hline Proline & 0.58 & 0.42 & -0.34 & -0.48 & -0.30 & -0.33 & -0.19 & -0.41 & 0.23 & -0.14 & -0.23 & -0.52 & 1 & & & & \\
\hline MDA & 0.59 & 0 & -0.73 & -0.11 & -0.40 & -0.50 & -0.31 & -0.01 & 0.27 & 0.24 & 0.05 & -0.28 & 0.49 & 1 & & & \\
\hline Chl & -0.57 & 0.65 & 0.21 & 0.34 & 0.52 & 0.34 & 0.36 & 0.50 & 0.66 & 0.67 & 0.48 & 0.76 & 0.45 & -0.61 & 1 & & \\
\hline Gs & -0.60 & 0.36 & 0.33 & 0.10 & 0.12 & 0.21 & 0.37 & 0.33 & 0.51 & 0.50 & 0.23 & 0.34 & -0.73 & -0.36 & 0.71 & 1 & \\
\hline $\mathbf{A}$ & -0.61 & 0.51 & 0.76 & 0.62 & 0.54 & 0.59 & 0.37 & 0.55 & 0.54 & 0.47 & 0.35 & 0.65 & -0.19 & -0.56 & 0.63 & 0.81 & 1 \\
\hline
\end{tabular}


The number of nodules per plant ranged between 92.50 and 100 . Similarly, V.B.N. 8 recorded the highest number of pods per plant (11.00), number of seeds per pod (5.67), pod length $(4.83 \mathrm{~cm})$, number of leaves per plant (59.00), 100-grain weight (4.23 g), and plant weight (18.60 g). The reduction was relatively higher in V.B.N. 3 in most growth and yield traits, signifying its sensitivity to ozone stress. Reduced photosynthetic capacity under elevated ozone conditions might, in turn, decrease the plant biomass by altering the allocation of photosynthates to several parts of the plant (Sarkar and Agrawal, 2010; Feng et al., 2011; Chaudhary et al., 2013; Ruiz-Vera et al., 2017; Ghosh et al., 2020). Similar results were observed in mung bean where the plant height and number of leaves per plant decreased by 25.7 and $24 \%$ under 70.9 ppb ozone stress (Chaudhary and Agarwal, 2015). The reduction in yield traits might be due to extended closure of stomata and decline in carbon fixation thereby reducing the availability of assimilates to its reproductive parts. Alterations in physiological and biochemical characteristics under ozone stress might in turn mighthave altered the growth and yield traits in blackgram varieties. V.B.N. 3 and V.B.N. 1 exhibited senescence due to ozone stress which might be ascribed due to the induction of genes associated with senescence (Miller et al., 1999). Similar results were also observed by Chaudhary and Agarwal (2015) in mung bean and by Ghosh et al. (2020) in maize. The relative root, plant length, number of nodules per plant, number of branches per plant, number of leaves per plant, and plant weight had a mean value of $88.32,96.89,92.50$, 84.66, 83.60, and $83.23 \%$ (Fig.3). The relative number of pods per plant, number of seeds per pod, pod length, and 100-grain weight had a mean value of $69.73,93.93,97.93$, and $91.85 \%$, respectively (Fig.4). The Pearson's correlation depicted a negative correlation between leaf injury percentage and other characteristics (Table 2). Similarly, a positive correlation was observed between stomatal conductance and photosynthetic rate, between chlorophyll content and photosynthetic rate, and between chlorophyll content and stomatal conductance. Likewise, linear relationship was observed between photosynthetic rate and growth traits (number of seeds per plant and pod length).

\section{CONCLUSION}

Understanding the influence of elevated tropospheric ozone on blackgram is highly imperative for global food security. The current study exhibited varietal variation among blackgram cultivars to ozone stress. Results indicate that elevated ozone concentration increased the leaf injury percentage, while all physiological traits like photosynthetic rate, stomatal conductance, and chlorophyll content declined significantly. Similarly, the malondialdehyde and proline content increased, while ascorbic acid content decreased under ozone stress. Significant reduction in the growth and yield traits were also observed in all blackgram varieties under ozone stress. This indicates that, among the blackgram varieties under study, V.B.N. 3 is sensitive and V.B.N. 8 is tolerant to ozone stress. Hence, this finding serves as a preliminary base to evaluate and assess the choice of cultivars to regions experiencing high tropospheric ozone concentration and for future breeding programmes. Varietal-specific alterations in plant attributes under ozone stress might pave the way for developing ozone-tolerant blackgram cultivars using genome mapping and quantitative trait loci (QTL)-based approaches, thereby boosting global production. Significant genetic heterogeneity in ozone sensitivity and tolerance across test cultivars might be helpful in creating models to anticipate ozone-induced yield loss and adaptation techniques for long-term cultivation.

\section{Funding and Acknowledgment}

The authors sincerely thank Tamil Nadu Agricultural University, Coimbatore for extending facilities and support in performing the experiments. Sincere thanks to Dr. S. Karthikeyan, Professor (Microbiology), T.N.A.U. for providing all infrastructure facilities to carry out the pot experiments.

\section{Ethics statement}

No specific permits were required for the described field studies because no human or animal subjects were involved in this research.

\section{Originality and plagiarism}

Authors ensure the originality of the manuscript and the work and/or words of others, has been appropriately cited. We acknowledge that plagiarism in all its forms constitutes unethical publishing behavior and is unacceptable.

\section{Consent for publication}

All the authors agreed to publish the content.

\section{Competing interests}

There were no conflict of interest in the publication of this content

\section{Data availability}

All the data of this manuscript are included in the M.S. No separate external data source is required.

\section{Author contributions}

Idea conceptualization - Periyasamy Dhevagi, Experiments- Periyasamy Dhevagi, Ramya Ambikapathi ,Guidance -Periyasamy Dhevagi, Writing original draft - Poornima Ramesh, Ramya Ambikapathi, Writing- reviewing \&editing - Periyasamy 
Dhevagi, Poornima Ramesh, Ramya Ambikapathi

\section{REFERENCES}

Agathokleous, E., Kitao, M. and Y. Kinose. 2018. A review study on ozone phytotoxicity metrics for setting critical levels in Asia. Asian J. Atmos. Environ., 12(1): 1-16.

Agathokleous, E., Saitanis, C.J. and T. Koike, T. 2015. Tropospheric $\mathrm{O}_{3}$, the nightmare of wild plants: a review study. J. Agric. Meteorol., 71(2): 142-152.

Agrawal, G.K., Rakwal, R., Yonekura, M., Kubo, A. and H. Saji. 2002. Proteome analysis of differentially displayed proteins as a tool for investigating ozone stress in rice (Oryza sativa L.) seedlings. Proteomics, 2(8): 947-959.

Agrawal, M., Singh, B., Agrawal, S.B., Bell, J.N.B. and F. Marshall. 2006. The effect of air pollution on yield and quality of mung bean grown in peri-urban areas of Varanasi. Water Air Soil Pollut., 169(1): 239-254.

Agrawal, S.B., Singh, A. and D. Rathore. 2005. Role of ethylene diurea (E.D.U.) in assessing impact of ozone on Vigna radiata L. plants in a suburban area of Allahabad (India). Chemosphere, 61(2): 218-228.

Ainsworth, E.A. 2017. Understanding and improving global crop response to ozone pollution. Plant J., 90(5): 886-897.

Ashrafuzzaman, M., Lubna, F.A., Holtkamp, F., Manning, W.J., Kraska, T. and M. Frei. 2017. Diagnosing ozone stress and differential tolerance in rice (Oryza sativa L.) with ethylenediurea (E.DU.). Environ. Pollut., 230: 339-350.

Bates, L.S., Waldren, R.P. and I.D. Teare. 1973. Rapid determination of free proline for water-stress studies. Plant soil., 39(1): 205-207.

Berntsen, T., Isaksen, I.S., Wang, W.C. and X.Z. Liang. 1996. Impacts of increased anthropogenic emissions in Asia on tropospheric ozone and climate: A global 3-D model study. Tellus B: Chem. Phys. Meteorol., 48(1): 13-32.

Betzelberger, A.M., Gillespie, K.M., Mcgrath, J.M., Koester, R.P., Nelson, R.L. and E.A. Ainsworth. 2010. Effects of chronic elevated ozone concentration on antioxidant capacity, photosynthesis and seed yield of 10 soybean cultivars. Plant Cell Environ., 33(9): 1569-1581.

Biswas, D.K. and G.M. Jiang. 2011. Differential droughtinduced modulation of ozone tolerance in winter wheat species. J. Exp. Bot., 62(12): 4153-4162.

Blokhina, O., Virolainen, E. and K.V. Fagerstedt. 2003. Antioxidants, oxidative damage and oxygen deprivation stress: a review. Ann. Bot., 91(2): 179-194.

Booker, F., Muntifering, R., McGrath, M., Burkey, K., Decoteau, D., Fiscus, E., Manning, W., Krupa, S., Chappelka, A. and D. Grantz. 2009. The ozone component of global change: potential effects on agricultural and horticultural plant yield, product quality and interactions with invasive species. J. Integr. Plant Biol., 51(4): 337-351.
Brasseur, G.P., Kiehl, J.T., Müller, J.F., Schneider, T., Granier, C., Tie, X. and D. Hauglustaine. 1998. Past and future changes in global tropospheric ozone: Impact on radiative forcing. Geophys. Res. Lett., 25(20): 3807-3810.

Brauer, M., Freedman, G., Frostad, J., Van Donkelaar, A., Martin, R.V., Dentener, F., Dingenen, R.V., Estep, K., Amini, H., Apte, J.S. and K. Balakrishnan. 2016. Ambient air pollution exposure estimation for the global burden of disease 2013. Environ. Sci. Technol., 50(1): 79-88.

Caregnato, F.F., Bortolin, R.C., Junior, A.M.D. and J.C.F. Moreira. 2013. Exposure to elevated ozone levels differentially affects the antioxidant capacity and the redox homeostasis of two subtropical Phaseolus vulgaris L. varieties. Chemosphere, 93(2): 320330.

Castagna, A., Nali, C., Ciompi, S., Lorenzini, G., Soldatini, G.F. and A. Ranieri. 2001. Ozone exposure affects photosynthesis of pumpkin (Cucurbita pepo) plants. New Phytol., 152(2): 223-229.

Chaudhary, N. and S.B. Agrawal. 2013. Intraspecific responses of six Indian clover cultivars under ambient and elevated levels of ozone. Environ. Sci. Pollut. Res., 20(8): 5318-5329.

Chaudhary, N. and S.B. Agrawal. 2015. The role of elevated ozone on growth, yield and seed quality amongst six cultivars of mung bean. Ecotoxicol. Environ. Saf., 111: 286-294.

Chaudhary, N., Singh, S., Agrawal, S.B. and M. Agrawal. 2013. Assessment of six Indian cultivars of mung bean against ozone by using foliar injury index and changes in carbon assimilation, gas exchange, chlorophyll fluorescence and photosynthetic pigments. Environ. Monit. Assess., 185(9): 77937807.

Cho, K., Tiwari, S., Agrawal, S.B., Torres, N.L., Agrawal, M., Sarkar, A., Shibato, J., Agrawal, G.K., Kubo, A. and R. Rakwal. 2011. Tropospheric ozone and plants: absorption, responses, and consequences. Rev. Environ. Contam. Toxicol., 212: 61-111.

Collins, W.J., Stevenson, D.S., Johnson, C.E. and R.G. Derwent. 1997. Tropospheric ozone in a globalscale three-dimensional Lagrangian model and its response to $\mathrm{NO} x$ emission controls. Atmos. Chem., 26(3): 223-274.

D.A.C. and F.W. 2018. Manual for Drought Management, December 2018. Department of Agriculture, Cooperation \& Farmers Welfare, Ministry of Agriculture \& Farmers Welfare, Government of India, New Delhi, pp. 154.

Danh, N.T., Huy, L.N. and N.T.K. Oanh. 2016. Assessment of rice yield loss due to exposure to ozone pollution in Southern Vietnam. Sci. Total Environ., 566: 1069-1079.

Daszkowska-Golec, A. and I. Szarejko. 2013. The molecular basis of ABA-mediated plant response to drought. Abiotic stress-plant responses and applications in agriculture, pp.103-134.

Elvira, S., Bermejo, V., Manrique, E. and B.S. Gimeno. 2004. On the response of two populations of 
Quercus coccifera to ozone and its relationship with ozone uptake. Atmos. Environ., 38(15): 2305-2311.

Feng, Z. and K. Kobayashi. 2009. Assessing the impacts of current and future concentrations of surface ozone on crop yield with meta-analysis. Atmos. Environ., 43(8): 1510-1519.

Feng, Z., Kobayashi, K. and E.A. Ainsworth. 2008. Impact of elevated ozone concentration on growth, physiology, and yield of wheat (Triticum aestivum L.): a meta-analysis. Glob. Change Biol., 14(11): 2696-2708.

Feng, Z., Pang, J., Kobayashi, K., Zhu, J. and D.R. Ort. 2011. Differential responses in two varieties of winter wheat to elevated ozone concentration under fully open-air field conditions. Glob. Change Biol., 17(1): 580-591.

Fiscus, E.L., Booker, F.L. and K.O. Burkey. 2005. Crop responses to ozone: uptake, modes of action, carbon assimilation and partitioning. Plant Cell Environ., 28(8): 997-1011.

Flowers, M.D., Fiscus, E.L., Burkey, K.O., Booker, F.L. and J.J.B. Dubois. 2007. Photosynthesis, chlorophyll fluorescence, and yield of snap bean (Phaseolus vulgaris L.) genotypes differing in sensitivity to ozone. Environ. Exp. Bot., 61(2): 190-198.

Gayathri, J., Boomiraj, K., Avudainayagam, S., Maheswari, M., Chandrasekhar, C.N. and S. Karthikeyan. 2019. Impact of tropospheric ozone on growth and yield of garlic in high altitude region of Western Ghats. Int. J. Commun. Soc., 7(3): 3099-3101.

Ghosh, A., Pandey, B., Agrawal, M. and S.B. Agrawal. 2020. Interactive effects and competitive shift between Triticum aestivum L. (Wheat) and Chenopodium album L.(fat-hen) under ambient and elevated ozone. Environ. Pollut., 265: 114764.

Ghude, S.D., Jena, C., Chate, D.M., Beig, G., Pfister, G.G., Kumar, R. and V. Ramanathan. 2014. Reductions in India's crop yield due to ozone. Geophys. Res. Lett., 41(15): 5685-5691.

Gill, S.S. and N. Tuteja. 2010. Reactive oxygen species and antioxidant machinery in abiotic stress tolerance in crop plants. Plant Physiol. Biochem., 48(12): 909-930.

Harmens, H., Hayes, F., Mills, G., Sharps, K., Osborne, S. and H. Pleijel. 2018. Wheat yield responses to stomatal uptake of ozone: Peak vs rising background ozone conditions. Atmos. Environ., 173: 1-5.

Hasanuzzaman, M., Hossain, M. A., da Silva, J. A. T. and M. Fujita. 2012. Plant response and tolerance to abiotic oxidative stress: antioxidant defense is a key factor. In: Crop stress and its management: perspectives and strategies, Springer, Dordrecht. pp. 261-315.

Heath, R.L. and L. Packer. 1968. Photoperoxidation in isolated chloroplasts: I. Kinetics and stoichiometry of fatty acid peroxidation. Arch. Biochem. Biophys., 125(1): 189-198.

I.P.C.C. 2007: Solomon, S. Climate change the physical science basis. In Agu fall meeting abstracts. pp. U43D-01.

Jing, L., Dombinov, V., Shen, S., Wu, Y., Yang, L., Wang, Y. and M. Frei. 2016. Physiological and genotypespecific factors associated with grain quality changes in rice exposed to high ozone. Environ. Pollut., 210: 397-408.

Keller, T. and H. Schwager. 1977. Air pollution and ascorbic acid. Eur. J. Plant Pathol., 7(6): 338-350.

McCrady, J.K. and C.P. Andersen. 2000. The effect of ozone on below-ground carbon allocation in wheat. Environ. Pollut., 107(3): 465-472.

Meehl, G.A., Stocker, T.F., Collins, W.D., Friedlingstein, P., Gaye, A.T., Gregory, J.M., Kitoh, A., Knutti, R., Murphy, J.M., Noda, A. and S.C. Raper. 2007. Global climate projections. Chapter 10. United Kingdom. 748-845.

Miller, J.D., Arteca, R.N. and E.J. Pell. 1999. Senescenceassociated gene expression during ozoneinduced leaf senescence in Arabidopsis. Plant Physiol., 120(4): 1015-1024.

Mills, G., Pleijel, H., Malley, C. S., Sinha, B., Cooper, O. R., Schultz, M. G., and A. Lewis. 2018. Tropospheric Ozone Assessment Report: Presentday tropospheric ozone distribution and trends relevant to vegetation. Elem. Sci. Anth., 6: 47.

Mishra, A.K. and S.B. Agrawal. 2015. Biochemical and physiological characteristics of tropical mung bean (Vigna radiata L.) cultivars against chronic ozone stress: an insight to cultivar-specific response. Protoplasma, 252(3): 797-811.

Mishra, A.K., Rai, R. and S.B. Agrawal. 2013. Differential response of dwarf and tall tropical wheat cultivars to elevated ozone with and without carbon dioxide enrichment: growth, yield and grain quality. Field Crops Res., 145: 21-32.

Mohan, S. and P. Saranya. 2019. Assessment of tropospheric ozone at an industrial site of Chennai megacity. J. Air Waste Manag. Assoc., 69(9): 1079-1095.

Monks, P.S., Archibald, A.T., Colette, A., Cooper, O., Coyle, M., Derwent, R., Fowler, D., Granier, C., Law, K.S., Mills, G.E. and D.S. Stevenson. 2015. Tropospheric ozone and its precursors from the urban to the global scale from air quality to short-lived climate forcer. Atmospheric Chem. Phys., 15(15): 8889-8973.

Murugaragavan, R. and C. Udayasoorian. 2016. Assessment of Visible Injury Impact due to Tropospheric Ozone. Adv. Life Sci., 5(2): 628-633.

Muthulakshmi, B., S.J. Jeyakumar, and S.V.I.K. Punithavathy. 2017. Diurnal and seasonal variations in ground level ozone (glo) and relationship with meteorological condition at residential area, Chennai, India. Asia Pac. J. Tour. Res., 1(L1): 85-91.

Oksanen, E., Pandey, V., Pandey, A. K., Keski-Saari, S., Kontunen-Soppela, S., and C. Sharma. 2013. Impacts of increasing ozone on Indian plants. Environ. Pollut., 177: 189-200.

Osborne, S., Pandey, D., Mills, G., Hayes, F., Harmens,

$107|10-12| 8$ 
H., Gillies, D., Büker, P. and L. Emberson. 2019. New insights into leaf physiological responses to ozone for use in crop modelling. Plants, 8(4): 84.

Padma, K., Selvaraj, R.S., Arputharaj, S. and B.M. Boaz. 2014. Improved artificial neural network performance on surface ozone prediction using principal component analysis. Int J. Curr. Res. Rev., 6(16): 1-6.

Pandey, J., Agrawal, M., Khanam, N., Narayan, D. and D.N. Rao. 1992. Air pollutant concentrations in Varanasi, India. Atmos. Environ.. Part B. Urban Atmos., 26(1): 91-98.

Prabakaran, P., Krishnasamy, V., Manikandan, A. and V. Rambabu. 2017. Consequence of meteorological factors on gaseous pollutants and seasonal erraticism in the ambient air of Chennai city. Indian J. Environ. Prot., 37(6): 461-474.

Prather, M., Gauss, M., Berntsen, T., Isaksen, I., Sundet, J., Bey, I., Brasseur, G., Dentener, F., Derwent, R., Stevenson, D. and L. Grenfell. 2003. Fresh air in the 21st century?. Geophys. Res. Lett., 30(2): 1100.

Pulikesi, M., Baskaralingam, P., Rayudu, V.N., Elango, D., Ramamurthi, V. and S. Sivanesan. 2006. Surface ozone measurements at urban coastal site Chennai, in India. J. Hazard. Mater., 137(3): 1554-1559.

Rai, R. 2020. Threat Imposed by $\mathrm{O}_{3}$-Induced ROS on Defense, Nitrogen Fixation, Physiology, Biomass Allocation, and Yield of Legumes. In The Plant Family Fabaceae. Springer, Singapore. pp. 503-517

Rai, R., Agrawal, M. and S.B. Agrawal. 2010. Threat to food security under current levels of ground level ozone: a case study for Indian cultivars of rice. Atmos. Environ., 44(34): 4272-4282.

Rai, R., Agrawal, M., Choudhary, K.K., Agrawal, S.B., Emberson, L. and P. Büker. 2015. Application of ethylene diurea (E.D.U.) in assessing the response of a tropical soybean cultivar to ambient $\mathrm{O}_{3}$ : Nitrogen metabolism, antioxidants, reproductive development and yield. Ecotoxicol. Environ. Saf., 112: 29-38.

Ramya, A., Maheswari, M., Jayabalakrishnan, R.M., Saraswathi, R. and C.N. Chandrasekhar. 2021. Assessment of Physiological, Biochemical and Yield Attributes of Rice Cultivars under Elevated Ozone Stress. Madras Agric. J., 107(10-12): 369-375.

Ramya, A., Dhevagi, P., Priyatharshini, S., Chandrasekhar, C.N., Valliappan, K. and S. Venkataramani. 2021. Physiological and Biochemical Response of Rice Cultivars (Oryza Sativa L.) To Elevated Ozone. Ozone Sci. Eng., 43(4): 363-377.

Rejeb, I.B., Pastor, V. and B. Mauch-Mani. 2014. Plant responses to simultaneous biotic and abiotic stress: molecular mechanisms. Plants, 3(4): 458-475.

Ruiz-Vera, U.M., De Souza, A.P., Long, S.P. and D.R. Ort. 2017. The role of sink strength and nitrogen availability in the down-regulation of photosynthetic capacity in field-grown Nicotiana tabacum L. at elevated $\mathrm{CO}_{2}$ concentration. Front. Plant Sci., 8:
998.

Salvatori, E., Fusaro, L., Mereu, S., Bernardini, A., Puppi, G. and F. Manes. 2013. Different $\mathrm{O}_{3}$ response of sensitive and resistant snap bean genotypes (Phaseolus vulgaris L.): the key role of growth stage, stomatal conductance, and PSI activity. Environ. Exp. Bot., 87: 79-91.

Sanmartin, M., Drogoudi, P.D., Lyons, T., Pateraki, I., Barnes, J. and A.K. Kanellis. 2003. Overexpression of ascorbate oxidase in the apoplast of transgenic tobacco results in altered ascorbate and glutathione redox states and increased sensitivity to ozone. Planta, 216(6): 918-928.

Sarkar, A. and S.B. Agrawal. 2010. Elevated ozone and two modern wheat cultivars: an assessment of dose dependent sensitivity with respect to growth, reproductive and yield parameters. Environ. Exp. Bot., 69(3): 328-337.

Sarkar, A., Singh, A.A., Agrawal, S.B., Ahmad, A. and S.P. Rai. 2015. Cultivar specific variations in antioxidative defense system, genome and proteome of two tropical rice cultivars against ambient and elevated ozone. Ecotoxicol. Environ. Saf., 115: 101-111.

Sawada, H. and Y. Kohno. 2009. Differential ozone sensitivity of rice cultivars as indicated by visible injury and grain yield. Plant Biol., 11: 70-75.

Saxena, P., Srivastava, A., Tyagi, M. and S. Kaur. 2019. Impact of tropospheric ozone on plant metabolism-a review. Pollut. Res., 38(1): 175180

Sethupathi, N., Boomiraj, K. and N. Sritharan. 2018. Effect of Elevated Ozone on Plant Nutrients, Chlorophyll Content and Antioxidant Enzymes in Cauliflower (Brassica oleracea var. botrytis L.). Madras Agric. J., 105(4-6): 220-224.

Sharma, K., and S. Nagaveena. 2016. Summer time variation and unexpected nocturnal peak in precursors related Surface ozone concentration in air over a tropical coastal region of Southern Tamil Nadu, India. Pollution, 2(4): 433-448.

Sharma, P., Jha, A.B., Dubey, R.S. and M. Pessarakli. 2012. Reactive oxygen species, oxidative damage, and antioxidative defense mechanism in plants under stressful conditions. J. Bot., Article ID 217037: 1-26.

Singh, A.A., Agrawal, S.B., Shahi, J.P. and M. Agrawal. 2014. Assessment of growth and yield losses in two Zea mays $L$. cultivars (quality protein maize and nonquality protein maize) under projected levels of ozone. Environ. Sci. Pollut. Res., 21(4): 2628-2641.

Singh, E., Tiwari, S. and M. Agrawal. 2009. Effects of elevated ozone on photosynthesis and stomatal conductance of two soybean varieties: a case study to assess impacts of one component of predicted global climate change. Plant Biol., 11: 101-108.

Singh, S. and S.B. Agrawal. 2010. Impact of tropospheric ozone on wheat (Triticum aestivum L.) in the eastern Gangetic plains of India as assessed by ethylenediurea (E.D.U.) application during different developmental stages. Agric. Ecosyst. 
Environ., 138(3-4): 214-221.

Sugai, T., Kam, D.G., Agathokleous, E., Watanabe, M., Kita, K. and T. Koike. 2018. Growth and photosynthetic response of two larches exposed to $\mathrm{O}_{3}$ mixing ratios ranging from preindustrial to near future. Photosynthetica, 56(3): 901-910.

Suganthy, V.S. and C. Udayasoorian. 2016. Assessing the impact of ambient ozone $\left(\mathrm{O}_{3}\right)$ on the growth and yield of potato genotypes (Solanum tuberosum L.) by using exposure indices over the high altitude of western Ghats location in Southern India. Asian J. Environ. Sci., 11(1): 102-105.

Sun, C., Zhao, N., Zhuang, Z., Wang, H., Liu, Y., Weng, X. and Z. Wu. 2014. Mechanisms and reaction pathways for simultaneous oxidation of NOx and SO2 by ozone determined by in situ IR measurements. J. Hazard. Mater., 274: 376-383.

Tetteh, R., Yamaguchi, M. and T. Izuta. 2016. Effect of ambient levels of ozone on photosynthetic components and radical scavenging system in leaves of African cowpea varieties. Afr. Crop Sci. J., 24(2): 127-142.

Tingey, D.T. and W.E. Hogsett. 1985. Water stress reduces ozone injury via a stomatal mechanism. Plant Physiol., 77(4): 944-947.

Tiwari, S., Rai, R. and M. Agrawal. 2008. Annual and seasonal variations in tropospheric ozone concentrations around Varanasi. Int. J. Remote Sens., 29(15): 4499-4514.

Tripathi, R. and S.B. Agrawal. 2012. Effects of ambient and elevated level of ozone on Brassica campestris L. with special reference to yield and oil quality parameters. Ecotoxicol. Environ. Saf., 85: 1-12.

Udayasoorian, C., Jayabalakrishnan, R.M., Suguna, A.R., Venkataramani, S. and S. Lal. 2013. Diurnal and seasonal characteristics of ozone and NOx over a high altitude Western Ghats location in Southern India. Adv. Appl. Sci. Res., 4(5): 309-320.

Usha, B.P., Chithambarathanu, T. and R.K. Sharma.
2018. Diurnal and Seasonal Variations of Surface Ozone with Meteorological Parameters at Urban Site, Balabackya Nagar, Tirunelveli, Tamil Nadu, India. Int. J. Recent Res., 1: 2349-7688.

Van Dingenen, R., Dentener, F.J., Raes, F., Krol, M.C., Emberson, L. and J. Cofala. 2009. The global impact of ozone on agricultural crop yields under current and future air quality legislation. Atmos. Environ., 43(3): 604-618.

Van Leeuwen, J. 2015. Proposed OS\&E requirement: measuring ozone dosage. Ozone Sci. Eng., 37(2): 191-192.

Vingarzan, R. 2004. A review of surface ozone background levels and trends. Atmos. Environ., 38(21): 34313442.

Wedow, J.M., Ainsworth, E.A. and S. Li. 2021. Plant biochemistry influences tropospheric ozone formation, destruction, deposition, and response. Trends Biochem. Sci., 46(12): 9921002.

Williams, J., Keßel, S.U., Nölscher, A.C., Yang, Y., Lee, Y., Yáñez-Serrano, A.M., Wolff, S., Kesselmeier, J., Klüpfel, T., Lelieveld, J. and M. Shao. 2016. Opposite $\mathrm{OH}$ reactivity and ozone cycles in the Amazon rainforest and megacity Beijing: Subversion of biospheric oxidant control by anthropogenic emissions. Atmos. Environ., 125: 112-118.

Ziemke, J.R., Oman, L.D., Strode, S.A., Douglass, A.R., Olsen, M.A., McPeters, R.D., Bhartia, P.K., Froidevaux, L., Labow, G.J., Witte, J.C. and A.M. Thompson. 2019. Trends in global tropospheric ozone inferred from a composite record of TOMS/ OMI/MLS/OMPS satellite measurements and the MERRA-2 GMI simulation. Atmospheric Chem. Phys., 19(5): 3257-3269. 